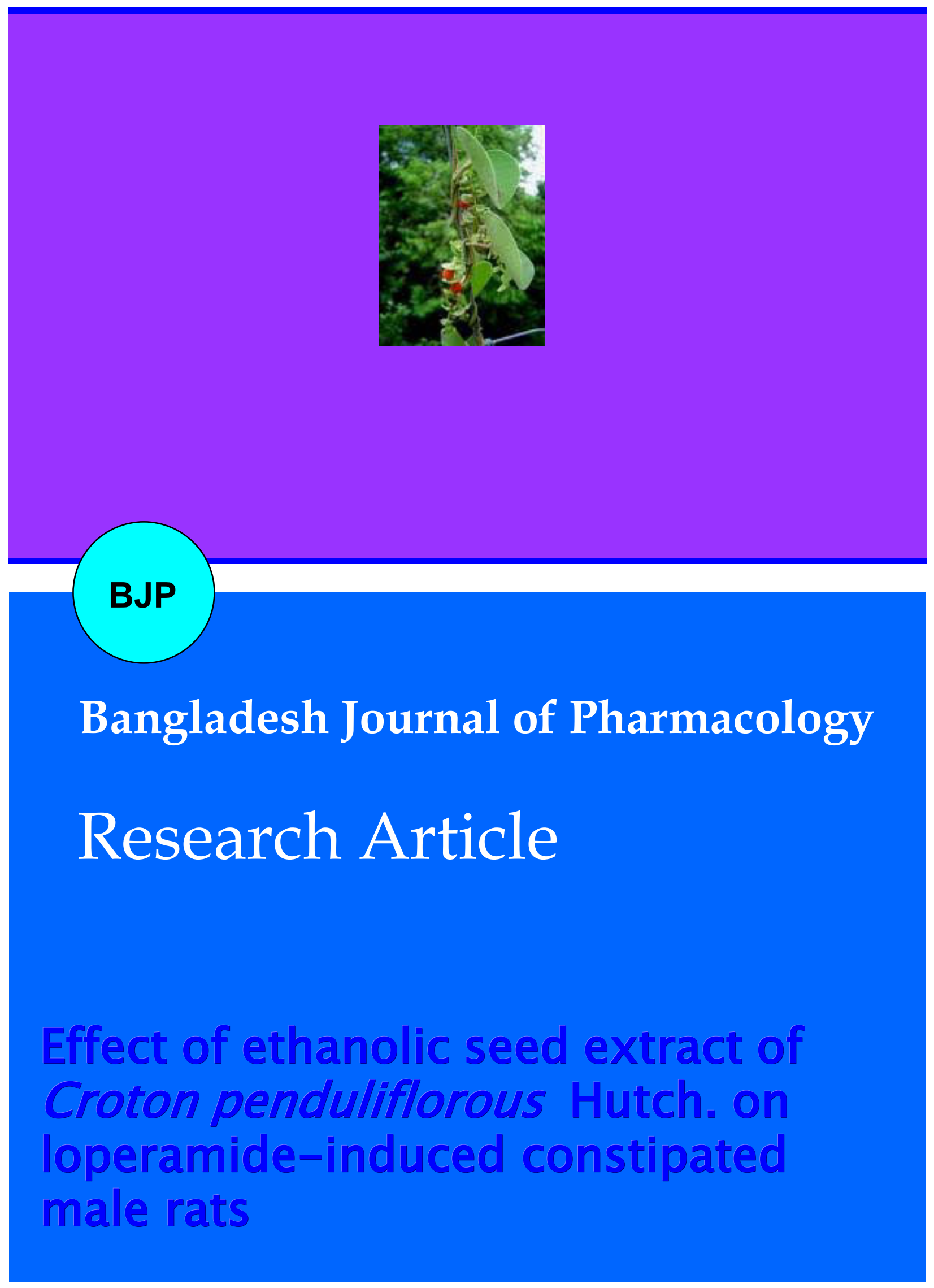


Abstracted/indexed in Academic Search Complete, Asia Journals Online, Bangladesh Journals Online, Biological Abstracts, BIOSIS Previews, CAB Abstracts, Current Abstracts, Directory of Open Access Journals, EMBASE/Excerpta Medica, Google Scholar, HINARI (WHO), International Pharmaceutical Abstracts, Open J-gate, Science Citation Index Expanded, SCOPUS and Social Sciences Citation Index;

ISSN: $1991-0088$

\title{
Effect of ethanolic seed extract of Croton penduliflorus Hutch. on loperamide-induced constipated male rats
}

\author{
Anofi Omotayo Tom Ashafa', Musa Toyin Yakubu², Abdul-Azeez Adeola Ogbe3 and \\ Aishat Abidemi Abass 3 \\ ${ }^{1}$ Department of Plant Sciences, University of the Free State, QwaQwa campus, Phuthaditjhaba 9866, South Africa; \\ ${ }^{2}$ Phytomedicine, Toxicology and Reproductive Biochemistry Research Laboratory, Department of Biochemistry, \\ University of Ilorin, Ilorin, Nigeria; ${ }^{3}$ Department of Botany, Lagos State University, Ojo Campus, Lagos, Nigeria.
}

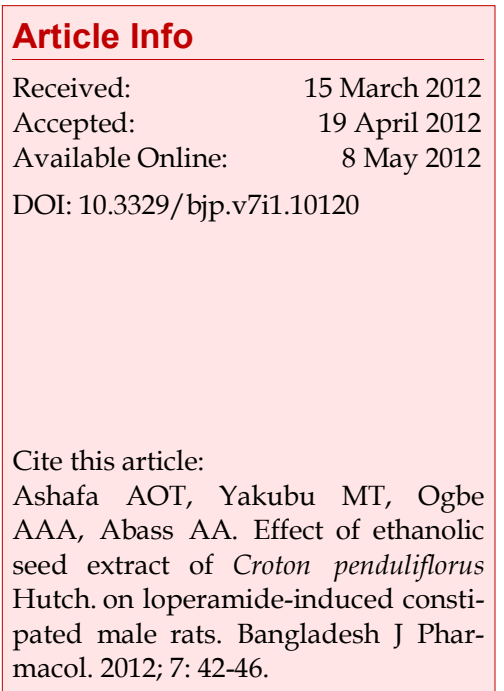

\begin{abstract}
The laxative effect of ethanolic seed extract of Croton penduliflorus was evaluated in loperamide-induced constipated male rats on daily basis for 7 days. The loperamide significantly $(\mathrm{p}<0.05)$ reduced the feed and water intake and the fecal parameters (number, water content and weight). The feed and water intake, number, water content and weight of fecal pellets were significantly reduced in both the constipated and $200 \mathrm{mg} / \mathrm{kg}$ body weight treated animals whereas these parameters increased in the $50 \mathrm{mg} / \mathrm{kg}$ body weight. The extract at $100 \mathrm{mg} / \mathrm{kg}$ body weight produced values that compared with the unconstipated and senokot-treated animals. The body weight was not significantly altered in the 50,100 and senokot-treated group whereas it was increased significantly in the constipated animals. The GIT ratio decreased in both the loperamide and $200 \mathrm{mg} / \mathrm{kg}$ body weight of the extract whereas the ratio at the 50 and $100 \mathrm{mg} / \mathrm{kg}$ body weight of the extract compared well with control animals. Overall, the ethanolic seed extract of $C$. penduliflorus produced a profound laxative activity against loperamideinduced constipated rats.
\end{abstract}

\section{Introduction}

Constipation is a highly prevalent, chronic functional gastrointestinal disorder affecting $3-15 \%$ of the general population (Higgins and Johanson, 2004; MullerLissner, 2009; Wintola et al., 2010; Meite et al., 2010). Etiological factors of constipation include metabolic problems, fibre deficiency, anorectal problems and drugs. Constipation which can be managed with diverse drugs such as senna, correctol, exlax, senokot and gaviscon are also associated with shortcomings like high cost, slow and low efficacy over time. Furthermore, almost half of the patients with constipation are not satisfied with the efficacy of orthodox laxatives in improving quality of life (Bengtsson and Ohlsson, 2005; Johanson and Kralstein, 2007). Therefore, the continu- ous search for a more natural, effective, affordable and readily available laxative in botanicals is imperative. One plant of interest is Croton penduliflorus.

C. penduliflorus (family:Euphorbiaceae) is an important medicinal plant in southern Nigeria where it is known as aworoso by the Yorubas. It is extensively used as a remedy for several stomach complaints including constipation (Adesogan, 1981). The seeds are roasted, ground and incorporated in a ball of "fufu" (Nigerian food made from cassava) to induce purgation (Azuzu et al., 1989). It is also claimed to be used in the management of cancer, constipation, diabetes, dy s en tery, w o u n d s, f e v e r, hypercholesterolemia, hypertension, inflammation, intestinal worms, malaria, pain, fibroid, ulcers and weight loss (Salatino et al., 2007; 
Odugbemi, 2008; Babalola, 2009; Ojokuku et al., 2011). In addition, the plant has also been claimed to have abortifacient and contraceptive activities (Adjanohoun et al., 1991; Odesanmi et al., 2006).

Previous reports have shown that C. penduliflorus seed oil contain purgative principles, antimicrobial, antivenom, antiparalytical, rubefacient and antitumor activities (Azuzu et al., 1988; 1989; Ojokuku et al., 2011). Acute toxicity study of the seed oil at the doses of 250, 600 and $800 \mathrm{mg} / \mathrm{kg}$ in mice adversely affected certain organs of the animals (Azuzu and Chineme, 1988; Ojokuku et al., 2010). Despite all these studies which focussed mainly on the seed oil, there is none in the open scientific literature that has addressed the laxative effect of the ethanolic extract of C. penduliflorus seeds in rats. Therefore, the present study investigated the effect of the solvent extract of C. penduliflorus seeds at the ethnobotanically informed doses of 50, 100 and 200 $\mathrm{mg} / \mathrm{kg}$ body weight on loperamide-induced constipated rats.

\section{Materials and Methods}

\section{Plant materials}

C. penduliflorus seeds were purchased at Iyana-Iba herbal market in Ojo Lagos State, Nigeria. The seeds were authenticated by Prof. O. A. Oke of the Department of Botany, Lagos State University, Nigeria. A voucher specimen (AshMed. 2010/LHB02) was deposited in the Departmental Herbarium.

\section{Drugs and chemicals}

Loperamide hydrochloride was a product of Jiangxi Xier Kangtai Pharmaceutical Co., Pingxiang, Jiangxi, China, while carmine and carboxymethylcellulose were from Sigma Chemical Co., USA. Senekot was a product of Reckitt Benckiser Pharmaceutical (Pty) Ltd, South Africa. All other chemicals and reagents used were of analytical grade.

\section{Animals}

Male, albino rats (Rattus norvegicus) of Wistar strain with a mean weight of $160.4 \pm 3.9 \mathrm{~g}$ were bred in the animal house of the Department of Biochemistry, Lagos State University, Nigeria. The animals were housed individually in clean aluminum cages placed in a wellventilated house with optimum condition (temperature $22 \pm 3^{\circ} \mathrm{C}$, photoperiod; 12 hours natural light and 12 hours dark; humidity; $45-50 \%$ ). The acclimatization was for 7 days during which the animals were allowed free access to commercial rat chow (Lagos State AgroProducts, Agric Farm, Ojo, Lagos) and water ad libitum. The cleaning of the cages was done daily. Animal handling were in accordance with the guidelines on the use and care of animals described by European Treaty Series (ETS, 2005).

\section{Preparation of ethanolic extract}

The dried seeds were pulverised and $40 \mathrm{~g}$ of the material was extracted in $500 \mathrm{~mL}$ of ethanol with constant shaking for 24 hours. This was filtered using Whatman No 1 (70 $\mathrm{mm})$ filter paper and thereafter concentrated using a rotary evaporator at $45^{\circ} \mathrm{C}$ to give a yield of $3.4 \mathrm{~g}$. This was reconstituted in normal saline to give the required doses of 50,100 and $200 \mathrm{mg} / \mathrm{kg}$ body weight for the experiment.

\section{Induction of constipation in the rats}

Constipation was induced in the animals by oral administration of $1 \mathrm{~mL}$ of loperamide $(3 \mathrm{mg} / \mathrm{kg}$ body weight in $0.9 \%$ sodium chloride for 3 days) (Bustos et al., 1991). The passage of reduced, hard and dry fecal pellets by the rats was used as a measure of constipation.

\section{Experimental design}

A total of 36 Wistar rats were grouped into six (1-6) comprising of six animals each. Animals in Group 1 (non-constipated control) were administered with $1 \mathrm{~mL}$ of normal saline while those in groups 2, 3, 4, 5 and 6 were all induced with constipation and administered with $1 \mathrm{~mL}$ each of normal saline, $5 \mathrm{mg} / \mathrm{kg}$ body weight of senokot, 50, 100 and $200 \mathrm{mg} / \mathrm{kg}$ body weight/day of ethanolic seed extract of C. penduliflorus respectively. The administration was done once daily for 7 days using metal oropharyngeal cannula.

\section{Indices of constipation monitored}

The water intake, feed intake and body weight gain of all the rats were recorded during experimental period of 7 days. Furthermore, fecal pellets from each rat were collected on daily basis at 09:00 hours throughout the duration of the experiment and their total number, weight and water content determined. The water content was computed as the difference between the wet and dry weights of the pellet.

\section{Gastrointestinal transit (GIT) ratio}

GIT ratio was determined according to the procedure described by Nakagura et al. (1996). Briefly, on the 7th day of extract administration, $1 \mathrm{~mL}$ of carmine $(3 \mathrm{~g}$ of carmine suspended in $50 \mathrm{~mL}$ of $0.5 \%$ carboxymethylcellulose) was orally administered to the rats. An hour after the administration of the marker (carmine), the animals were humanely sacrificed and the small intestines quickly and carefully removed. The distance covered by the carmine and the total length of the small intestine were measured. The GIT ratio was expressed as percentage of the distance travelled by the carmine relative to the total length of the small intestine. 


\section{Table I}

Effect of administration of loperamide on feed intake, water intake, and fecal parameters of rats

\begin{tabular}{|lcc|}
\hline Parameters & Normal control & Loperamide-induced constipated animals \\
\hline Feed intake $(\mathrm{g})$ & $16.8 \pm 1.2 \mathrm{a}$ & $8.8 \pm 1.0 \mathrm{~b}$ \\
Water intake $(\mathrm{g})$ & $20.9 \pm 1.3 \mathrm{a}$ & $9.8 \pm 0.8 \mathrm{~b}$ \\
Number of fecal pellets & $71.1 \pm 3.8 \mathrm{a}$ & $26.4 \pm 1.0 \mathrm{~b}$ \\
Water content of fecal pellets $(\mathrm{g})$ & $1.7 \pm 0.2 \mathrm{a}$ & $0.6 \pm 0.1 \mathrm{~b}$ \\
Weight of fecal pellets $(\mathrm{g})$ & $7.0 \pm 0.5 \mathrm{a}$ & $3.2 \pm 0.1 \mathrm{~b}$ \\
\hline
\end{tabular}

$\mathrm{n}=6 \pm$ SEM; Values for each parameter carrying superscript different from the non-constipated control are significantly different ( $\mathrm{p}<0.05$ );

Values in brackets are the computed percentage decrease

\section{Table II}

\section{Effect of ethanolic seed extract of $C$. penduliflorus on some indices of constipation}

\begin{tabular}{|c|c|c|c|c|c|c|}
\hline \multirow[t]{2}{*}{ Parameters } & \multirow[t]{2}{*}{$\begin{array}{l}\text { Normal } \\
\text { control }\end{array}$} & \multirow[t]{2}{*}{$\begin{array}{l}\text { Constipat- } \\
\text { ed control }\end{array}$} & \multirow[t]{2}{*}{$\begin{array}{l}\text { Senekot (5 mg/ } \\
\quad \mathrm{kg} \mathrm{b} / \mathrm{w})\end{array}$} & \multicolumn{3}{|c|}{$\begin{array}{l}\text { Constipated animals plus Extract (mg/kg } \\
\text { body weight) }\end{array}$} \\
\hline & & & & 50 & 100 & 200 \\
\hline Feed intake (g) & $25.3 \pm 1.6 \mathrm{a}$ & $14.7 \pm 1.4 \mathrm{~b}$ & $23.1 \pm 1.2 \mathrm{a}$ & $44.0 \pm 2.0 \mathrm{c}$ & $24.3 \pm 1.1 \mathrm{a}$ & $15.3 \pm 0.2 b$ \\
\hline Water intake (mL) & $53.8 \pm 2.6 \mathrm{a}$ & $42.8 \pm 2.9 b$ & $53.4 \pm 2.9 \mathrm{a}$ & $40.8 \pm 4.1 b$ & $51.4 \pm 5.6 \mathrm{a}$ & $39.8 \pm 5.2 b$ \\
\hline Number of fecal pellets & $77.8 \pm 2.6 a$ & $36.8 \pm 4.9 b$ & $78.0 \pm 3.5 \mathrm{a}$ & $139.1 \pm 7.9 \mathrm{c}$ & $76.6 \pm 3.2 \mathrm{a}$ & $54.7 \pm 3.1 d$ \\
\hline $\begin{array}{l}\text { Water content of fecal pellets } \\
\text { (g) }\end{array}$ & $2.1 \pm 0.1 \mathrm{a}$ & $1.0 \pm 0.04 b$ & $2.1 \pm 0.1 \mathrm{a}$ & $5.1 \pm 0.1 c$ & $2.0 \pm 0.05 a$ & $1.7 \pm 0.1 \mathrm{~d}$ \\
\hline Weight of fecal pellets (g) & $8.8 \pm 0.6 \mathrm{a}$ & $3.9 \pm 0.3 b$ & $9.0 \pm 0.2 \mathrm{a}$ & $15.7 \pm 1.1 \mathrm{c}$ & $8.6 \pm 0.5 a$ & $8.5 \pm 0.5 a$ \\
\hline Body weight gain $(\mathrm{g})$ & $13.2 \pm 1.0 \mathrm{a}$ & $31.8 \pm 1.0 \mathrm{~b}$ & $13.2 \pm 1.1 \mathrm{a}$ & $12.5 \pm 2.1 \mathrm{a}$ & $12.6 \pm 2.0 \mathrm{a}$ & $9.0 \pm 0.1 c$ \\
\hline
\end{tabular}

$\mathrm{n}=6 \pm$ SEM; Values for each parameter carrying superscript different from the normal saline control are significantly different ( $\mathrm{p}<0.05)$

\section{Statistical analysis}

Data were expressed as means \pm SEM of six replicates and were subjected to one-way analysis of variance (ANOVA) followed by Duncan multiple range test for statistical difference. Values were considered statistically significant at $\mathrm{p}<0.05$.

\section{Results}

Compared with the unconstipated normal saline treated animals, the loperamide significantly $(p<0.05)$ reduced the feed and water intake by 48 and $53 \%$ respectively (Table I). In addition, the fecal parameters (number, water content and weight) reduced significantly in the loperamide treated animals (Table I).

The feed intake, water intake, number of fecal pellets, water content of pellets and weight of fecal pellets were significantly reduced in the loperamide $200 \mathrm{mg} / \mathrm{kg}$ body weight treated animals (Table II). In contrast, the $50 \mathrm{mg} / \mathrm{kg}$ body weight of the extract increased these parameters of constipation. The extract at $100 \mathrm{mg} / \mathrm{kg}$ body weight produced values of feed intake, water intake, number of fecal pellets, water content of fecal pellets and weight of fecal pellets that compared favorably $(p>0.05)$ with the non-constipated normal saline and senokot treated positive control animals (Table II). Administration of senokot, 50 and $100 \mathrm{mg} /$ $\mathrm{kg}$ body weight of the extract did not significantly alter the body weight of the animals when compared with the normal saline administered animals whereas the body weight of the constipated animals increased significantly. The $200 \mathrm{mg} / \mathrm{kg}$ body weight of the extract reduced the body weight of the animals significantly (Table II).

Treatment with loperamide decreased the GIT ratio of the animals (Figure 1). This pattern of decrease was extended to the animals administered with $200 \mathrm{mg} / \mathrm{kg}$ body weight of the extract. In contrast, the 50 and 100 $\mathrm{mg} / \mathrm{kg}$ body weight of the extract produced GIT ratio that compared well with both the normal saline and senokot treated animals (Figure 1). 


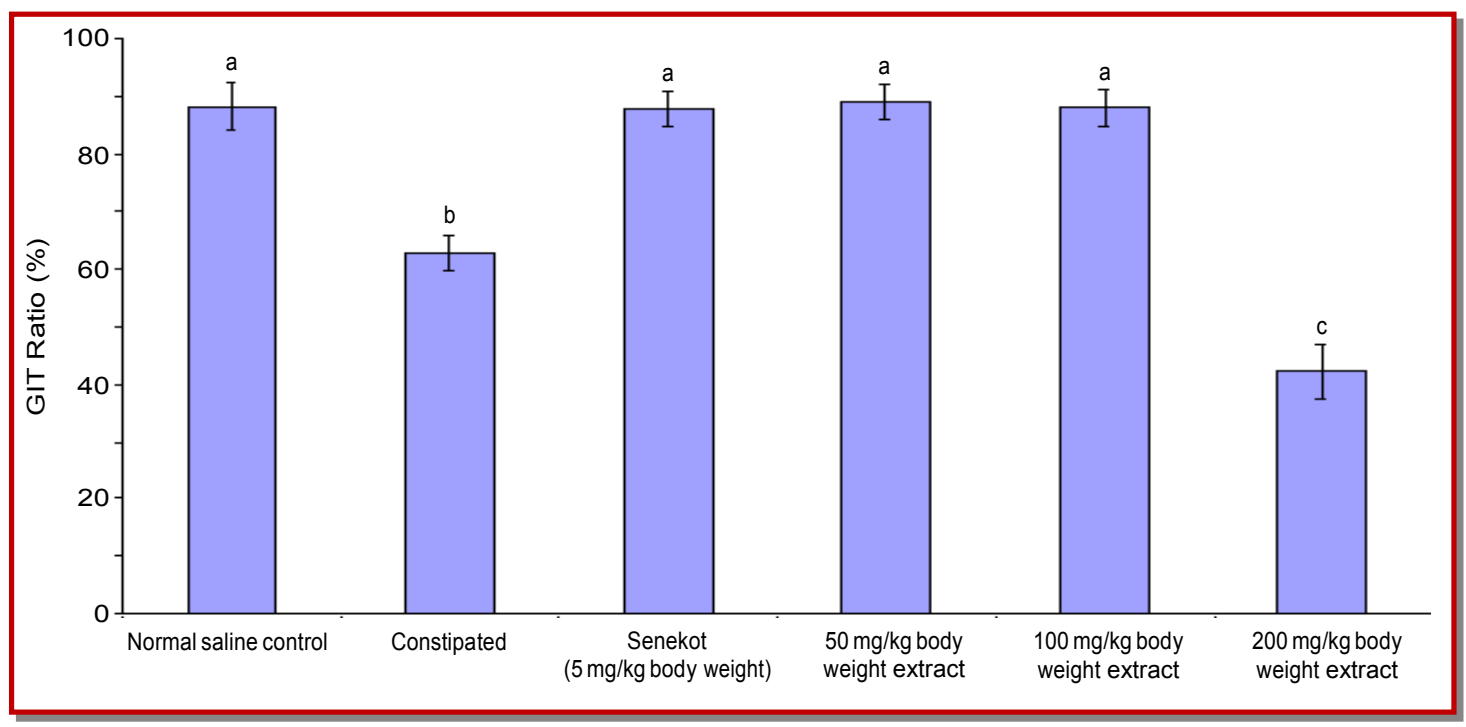

Figure 1: GIT ratio of C. penduliflorus seed extract-treated constipated rats

\section{Discussion}

Medicinal plants are now sources of direct therapeutic agents or as new raw material base for the synthesis of useful drugs. Greater percentage of the populace now depend on herbal remedies for the treatment of constipation since the orthodox laxatives are becoming increasingly expensive, unaffordable, slow-acting with its undesirable toxicological effects such as nausea, flatulence, abnormal cramping, diarrhea, colonic damage and colorectal cancer (Kot and Pettit-Young, 1992; Gattuso and Kamm, 1993; Fasola and Egunyomi, 2005; Obi et al., 2006). The present study has revealed a dose specific pharmacological activity of the ethanolic seed extract of $C$. penduliflorus.

Loperamide-induced constipation is a widely used model for spastic constipation (Takasaki et al., 1994). It causes constipation in animals by inhibiting intestinal water secretion (Hughes et al., 1984) and colonic peristalsis (Sohji et al., 1978) which consequentially affects the flow entering the colon (Lawrence et al. 1986). These inhibitory activities extend fecal evacuation time and consequently delays intestinal luminal transit (Yamada and Onoda, 1993).

In the present study, loperamide induced constipation in the animals as evidenced by the reduction in the feed intake, water intake as well as the fecal parameters. This further corroborates the use of loperamide to induce constipation.

Interestingly, the extract demonstrated a dose specific laxative activity since it was only the $100 \mathrm{mg} / \mathrm{kg}$ body weight that produced the desired results that could be regarded as laxative. For instance, it was only the 100 $\mathrm{mg} / \mathrm{kg}$ body weight of the extract that produced similar values of indices of constipation monitored in the present study to that of the reference drug, senokot and the non constipated normal saline treated control. The $50 \mathrm{mg} / \mathrm{kg}$ body weight appears to induce diarrhea whereas the reverse was the case for the $200 \mathrm{mg} / \mathrm{kg}$ body weight. The possible bowel movement in the loperamide-induced constipated rats by the extract at $100 \mathrm{mg} / \mathrm{kg}$ body weight further suggest laxative activity at this dose. The reversion of the feed and water intake in $100 \mathrm{mg} / \mathrm{kg}$ body weight treated animals also buttresses the laxative activity in the extract at this dose. It is also worthy of mention that the $100 \mathrm{mg} / \mathrm{kg}$ body weight of the extract may not predispose to overweight whereas the constipated rats administered normal saline gained weight probably due to accumulated fecal pellets in their body (Wintola et al., 2010) resulting from suppressed colonic movement.

The transit process of the entire gastrointestinal tract reflects an overall gastrointestinal motor activity. Therefore, the increase in the GIT ratio by the extract suggests enhanced intestinal motility and colonic peristalsis in the animals. This may be due to the ability of the extract to stimulate the release of fluid which increased the intestinal secretion.

Overall, this study has revealed that oral administration of ethanolic seed extract of C. penduliflorus exhibited dose specific laxative activity at $100 \mathrm{mg} / \mathrm{kg}$ body weight in loperamide-induced constipated animals.

\section{References}

Adesogan EK. The structure of penduliflaworosin, a new furanoid diterpene from Croton penduliflous. J Chem Soc Perkin Trans. 1981; 1: 1151-53.

Adjanohoun E, Ahiyi MRA, Assi LA, Dramane K, Eewude JA. Tradition al medicine and pharmacopoeia: Contribution to ethnobotanical and organization of Africa. Unity/ 
Scientific Technical and Research Commission, 1991, p 420.

Azuzu JU, Shetly SW, Anika SM. The toxic effect of chronic administration of gut-stimulating principle of Croton penduliflous Hutch seed in mice. Drug Chem Toxicol. 1989; 12: 85-93.

Azuzu IU, Chineme CN. Acute toxicity and gastrointestinal irritant effect of Croton penduliflorus seed oil in mice. Phytoter Res. 1988; 2: 46-50.

Azuzu IU, Gray AI, Waterman PG. The extraction, isolation and identification of the purgative component of Croton penduliflorus seed oil. J Ethnopharmacol. 1988; 23: 267-71.

Babalola AK. An examination of the usage of herbal contraceptives and abortifacients in Lagos State, Nigeria. Ethnobot Leaflets. 2009; 13: 146-46.

Bengtsson M, Ohlsson B. Psychological well-being and symptoms in women with chronic constipation treated with sodium picosulphate. Gastroenterol Nurs. 2005; 28: 3-12.

Bustos D, Ogawa K, Pons S, Soriano E, Banji JC, Bustos FL. Effect of loperamide and bisacodyl on intestinal transit time, fecal weight and short chain fatty acid excretion in the rat. Acta Gastroenterol Latinoam. 1991; 21: 3-9.

Fasola TR, Egunyomi A. Nigerian usage of bark in phytomedicine. Ethno Res Appli. 2005; 3: 73-77.

Gattuso JM, Kamm MA. The management of constipation in adults. Alimen Pharmacol Ther. 1993; 7: 487-500

Higgins PD, Johanson JF: Epidemiology of constipation in North America: A systematic review. Am J Gastroenterol. 2004; 99: 750-59.

Hughes JR, Hatsukami DK, Pickens RW, Krahn D, Malin, S, Luknic A. Effect of nicotine on the tobacco withdrawal syndrome. Psychopharmacology 1984; 83: 82-87.

Johanson JF, Kralstein J: Chronic constipation: A survey of the patient perspective. Aliment Pharmacol Ther. 2007; 25: 599608 .

Kot TV, Pettit-Young NA. Lactulose in the management of constipation: A current review. Ann Pharmacother. 1992; 26: 1277-82.

Lawrence RS, Carol ASA, Stephen GM, John SF. Mechanism of the antidiarrheal effect of loperamide. Gastroenterology 1984; 86: 1475-80.

Meite S, Bahi C, Yeo D, Datte JY,Djaman JA, N'guessan DJ. Laxative activities of Mareya micrantha (Benth.) Mull. Arg.
(Euphorbiaceae) leaf aqueous extract in rats. BMC Compl Alter Med. 2010; 10: 7.

Muller-Lissner S: The patholophysiology, diagnosis and treatment of constipation. Dtsch rtztebl Int. 2009; 106: 424-32.

Obi RK, Iroagba II, Ojiako OA. Virucidal potential of some edible Nigerian vegetables. Afr J Biotechnol. 2006; 5: 1785-88.

Odesanmi OS, Saibu GM, Ojokuku SA, Faremi AT, Bakare RI, Banjo AF. Comparative metabolic and histophatological effects of Croton penduliflorus (a herbal abortifacient) and depo provera in non-pregnant and pregnant Dutch white rabbits. In: Traditional and modern health systems in Nigeria. Falola T, Heaton M (eds). Eritrea, Africa World Press, 2006, pp 130-46.

Odugbemi T. A textbook of medicinal plants from Nigeria. Nigeria, University of Lagos Press, 2008, p 588.

Ojokuku SA, Odesanmi OS, Magbagbeola OA. The effects of oral administration of Croton penduliflorus seed oil and medroxyprogesterone acetate on fasting blood sugar, lipid and haematology of pregnant rabbits. Intl J Trop Med. 2011; 6: 35-38.

Ojokuku SA, Odesanmi OS, Magbagbeola OA. The effects of oral administration of Croton penduliflorus seed oil and depo provera on liver and kidney functions of pregnant Dutch white rabbits. Int J Bio Chem Sci. 2010; 4: 424-31.

Nagakura Y, Naitoh Y, Kamato T, Yamano M, Miyata K: Compounds processing $5-\mathrm{HT}_{3}$ receptor antagonistic activity inhibit intestinal propulsion in mice. Eur J Pharmacol. 1996; 311: 67-72.

Salatino A, Salatino MLF, Negri G. Traditional uses, chemistry and pharmacology of croton espécies (Euphorbiaceae). J Braz Chem Soc. 2007; 18: 11-33

Shoji Y, Kawashima K, Shimizu M. Pharmacological studies of loperamide, an anti-diarrhea agent. Folia Pharmacol Jpn. 1978; 74: 155-63.

Takasaki K, Kishibayashi N, Ishii A, Karasawa A. Effects of KW-5092, a novel gastroprokinetic agent, on the delayed colonic propulsion in rats. Japan J Pharmacol. 1994; 65: 67-71.

Wintola OA, Sunmonu TO, Afolayan AJ. The effect of Aloe ferox Mill. in the treatment of loperamide-induced constipation in Wistar rats. BMC Gastroenterol. 2010; 10: 95.

Yamada K, Onoda Y. Comparison of the effects of T- 1850, yohimbine and naloxone on mouse colonic propulsion. J Smooth Muscle Res. 1993; 29: 47-53.

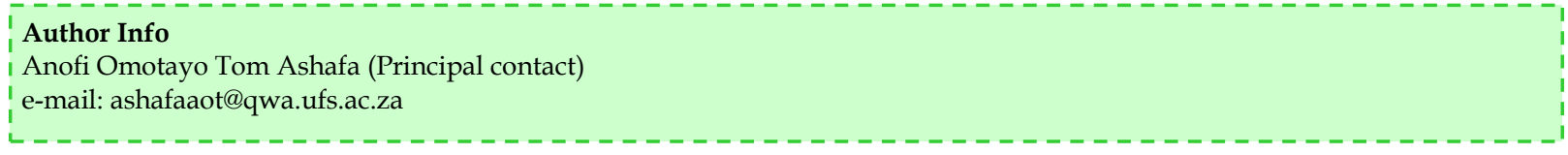

